Original Research

\title{
Membandingkan Kejadian Gangguan Gastrointestinal Penggunaan Aminofilin dan Salbutamol pada Pasien Eksaserbasi Asma di Surabaya
}

\author{
Amelia Lorensia ${ }^{1 *}$, Zullies Ikawati ${ }^{2}$, Tri Murti Andayani ${ }^{2}$, Daniel Maranatha ${ }^{3}$, Rizki \\ Amalia ${ }^{1}$ \\ 1 Fakultas Farmasi, Universitas Surabaya, Surabaya-Indonesia \\ 2 Departemen Farmakologi dan Farmasi Klinik, Fakultas Farmasi, Universitas Gadjah Mada, Yogyakarta- \\ Indonesia \\ 3 Departmen Pulmonologi dan IImu Kedokteran Respirasi, Fakultas Kedokteran, Universitas Airlangga, \\ Surabaya-Indonesia \\ *corresponding author: amelia.Iorensia@staff.ubaya.ac.id
}

\begin{abstract}
Asthma is a heterogeneous disease, which is characterized by inflammation of the respiratory tract with respiratory classification such as wheezing, shortness of breath, distress in the chest and coughing over time and intensity with variations in expiratory air flow. In Indonesia the prevalence of asthma is uncertain, it is not estimated that 2-5\% of Indonesia's population has asthma. The main objective of this study is to study gastrointestinal-related cases of the use of a minophylline and salbutamol in asthma exacerbation patients in hospitals in Surabaya and also to discuss gastrointestinal problems related to ADRs (Bad Drug Reactions) using the use of a minophylline and salbutamol on Naranjo scale. In this study using the Quasi Experimental method. This research was conducted in October 2014 to February 2015. The results of the study of 7 samples obtained $14.29 \%$ using ADR from the use of aminophylline and from 13 patients in the use of salbutamol was not found ADR can be used in accordance with the existing salbutamol in patients with asthma exacerbations at hospitals in Surabaya. The general benefits of this study are useful in monitoring the trea tment of acute as thma patients who need salbutamol and theophylline therapy so as to reduce the incidence of ADR.
\end{abstract}

Keywords: aminophylline, salbutamol, gastrointestinal disorders, asthma exacerbations

\begin{abstract}
Abstrak-Asma merupakan penyakit heterogen, yang ditandai dengan peradangan saluran napas kronis dengan disertai riwayat gejala pernapasan seperti mengi, sesak napas, rasa tertekan di dada dan batukdari waktu ke wa ktu dan intensitas dengan variasi keterbatasan aliran udara ekspirasi. Di Indonesia prevalensi asma belum diketahui secara pasti, namun diperkirakan 2-5\% penduduk Indonesia menderita asma. Tujuan uta ma penelitian ini adalah untuk mengeta hui perbedaan kejadian gangguan gastrointestinal pada penggunaan a minofilin dan salbutamol pada pasien eksaserbasi asma di Rumah Sakit di Surabaya serta mengetahui kejadian gangguan gastrointestinal terkait ADRs (Adverse Drug Reaction) akibat penggunaan aminofilin dan salbutamol berdasarkan penilaian Naranjo scale. Pada penelitian ini menggunakan metode Quasi Eksperimental. Penelitian ini dilakukan pada bulan Oktober 2014 sampai Februari 2015. Hasil penelitian dari 7 sampel diperoleh 14,29\% mengala mi ADR dari penggunaan aminofilin dan dari 13 pasien pada pengguanaan sal buta mol tidak ditemukan ADR sehingga dapat disimpul kan bahwa tidak a da perbeda an kejadian gangguan gastrointestinal pada penggunaan aminofilin dan salbutamol pada pasien eksaserbasi asma di Rumah Sakit di Surabaya. Manfaat umum dari penelitian ini adalah berguna dalam monitoring pengobatan pasien asma akut terutama yang menda pat terapi salbutamol dan teofilin sehingga da pat mengurangi angka kejadian ADR.
\end{abstract}

Kata kunci: aminofilin, salbutamol, gangguan gastrointestinal, eksaserbasi asma

\section{PENDAHULUAN}

Asma adalah penyakit heterogen yang ditandai dengan peradangan saluran napas kronis dengan disertai riwayat gejala pernapasan seperti mengi, sesak napas, rasa tertekan di dada dan batuk dari waktu ke waktu dan intensitas dengan variasi keterbatasan aliran udara ekspirasi [1]. Organisasi kesehatan dunia World Health Organization (WHO) memperkirakan 100-150 juta penduduk dunia menderita asma, jumlah ini diperkirakan akan terus bertambah sebesar 180.000 orang setiap tahun. Jumlah pasien asma sudah mencapai 300 juta orang di seluruh dunia dan terus meningkat selama 20 tahun belakangan ini. Disability Adjusted Life Year (DALYs) memperkirakan bahwa 15 juta setiap tahunnya karena asma, mewakili $1 \%$ dari total beban penyakit global. Kematian di seluruh dunia tahunan dari asma telah diperkirakan 
250.000 [2]. Di Indonesia diperkirakan 2-5\% penduduk Indonesia menderita asma [3]. Gejala asma yang tidak terkontrol dapat menyebabkan eksaserbasi asma, yaitu memburuknya gejala mengi, sesak napas, dada terasa tertekan benda berat dan batuk, atau kombinasi dari beberapa gejala ini. Pengobatan dini eksaserbasi asma adalah strategi terbaik untuk manajemen asma [4].

Tujuan dalam manajemen eksaserbasi asma adalah mengontrol gejala asma. Golongan short acting 6-2 agonist (SABA) inhalasi merupakan pilihan pertama pada pengobatan eksaserbasi asma, dan salbutamol adalah golongan SABA yang paling sering digunakan pada eksaserbasi asma untuk mengobati obstruksi jalan napas. Sal butamol merupakan lini pertama dalam pengobatan eksaserbasi asma [1], karena salbutamol merupakan stimulan $\beta 2$ adrenoceptor selektif yang menyebabkan otot polos bronkus berelaksasi melalui peningkatan intraseluler cyclic adenosine monophospate (cAMP) [4].

Menurut pedoman Global Initiative for Asthma [1], golongan methylxanthine digunakan sebagai terapi tambahan dalam manajemen eksaserbasi asma, dan yang paling sering digunakan adalah teofilin. Teofilin banyak digunakan secara luas di masyarakat Indonesia untuk terapi gejala sesak nafas pada asma karena harganya terjangkau, mudah didapat, dan bahkan diproduksi untuk obat OTC (over-the-counter) yang berarti penggunaannya di luar monitor tenaga kesehatan. Padahal di luar negeri teofilin sudah jarang digunakan karena sering menimbulkan adverse drug reaction (ADRs) dibandingkan golongan beta-2 agonis, seperti salbutamol. Teofilin memiliki efek bronkodilator dan anti inflamasi. Aksi bronkodilator tersebut berkaitan dengan PDE (phosphodiesterase enzyme) [5]. Sedangkan anti inflamasi pada penghambatan pada respon akhir (late response) terhadap alergen, meskipun juga memberikan sedikit efek pada respon awal. Hal ini telah diinterpretasikan sebagai efek pada respon inflamasi kronis, dan didukung oleh pengurangan infiltrasi dari eosinofil dan limfosit CD4+ ke dalam saluran pernafasan setelah alergen berikutnya masuk [5]. Aminofilin sering digunakan di rumah sakit di Indonesia $[6,7,8]$.

Aminofilin (teofilin) memiliki indeks terapi sempit, yang berarti jarak antar-dosis terapatik dan dosis toksik kecil sehingga efek toksik akan mudah timbul apabila dosis atau kadarnya melewati ambang toksik dan dapat terjadi ADRs yang tinggi sehingga pemantauan harus ditingkatkan [9]. Aminofilin sudah jarang digunakan di luar negeri karena sering menimbulkan ADRs (Adverse Drug Reaction) yang parah dan fatal. Namun di Indonesia, aminofilin justru termasuk dalam salah satu terapi eksaserbasi asma menurut Daftar Obat Essensial (DOEN) [10]. Beberapa penelitian retrospektif terdahulu menunjukkan bahwa pada penggunaan aminofilin pada pasien asma yang menjalani rawat inap, menunjukkan ADRs yang relatif ringan dan jarang, bahkan tidak ada ADRs $[6,7,8]$. Perbedaan kejadian ADRs dapat dikarenakan kejadian dari ADRs pada pasien dan dapat bersifat individual, sehingga perlu dilakukan pemantauan terhadap penggunaan aminofilin/teofilin pada pasien asma di Indonesia. Hal ini dikarenakan perbedaan ras atau etnik dapat menyebabkan adanya perbedaan disposisi dan nasib suatu obat serta adanya variabilitas inter individual kinetika distribusi dan eliminasi teofilin akan mengakibatkan terjadinya perbedaan kadar teofilin dalam plasma [11].

Gangguan gastrointestinal pada pasien yang mengalami eksaserbasi asma sering muncul bersamaan dan pada beberapa kasus gangguan gastrointestinal berkaitan dengan patogenesis asma [13], dan dapat berupa mual-muntah yang merupakan peristiwa awal yang paling umum [14]. Kejadian mual dari aminofilin sebanyak 1,05\% di Jepang [15]. Sedangkan di Indonesia, data mengenai persentase kejadian mual muntah akibat menggunakan aminofilin belum ditemukan. Antara mual-muntah pada asma memiliki beberapa keterkaitan. Mual dan muntah pada pasien asma dapat menyebabkan asam lambung naik, terutama pada pasien dengan GERD (Gastro Esophageal Reflux Disease). GERD menyebabkan regurgitasi yang dapat memengaruhi kualitas hidup pasien dan dapat memengaruhi gejala asma. Heartburn, regurgitasi, dan GERD terkait dengan masalah menelan. GERD akan menyebabkan rasa penuh sehingga akan merasa mual dan berlanjut pada muntah [16], bahkan dapat berisiko mengalami 
aspirasi yang dapat memperparah kondisi eksaserbasi asma [17]. Sebaliknya pada pasien asma yang mengalami batuk yang parah dapat menyebabkan muntah [18]. Tujuan utama penelitian ini adalah untuk mengetahui perbedaan kejadian gangguan gastrointestinal pada penggunaan aminofilin dan salbutamol pada pasien eksaserbasi asma di Rumah Sakit di Surabaya.

\section{METODE}

\section{Jenis Penelitian}

Jenis penelitian yang dipergunakan adalah metode penelitian quasi experimental. Subjek dibagi menjadi 2 kelompok yaitu kelompok obat A (diberi aminofilin intravena) dan kelompok B (diberi terapi salbutamol nebulizer) pada rumah sakit yang berbeda; satu rumah sakit akan mewakili salah satu kelompok obat. Penelitian ini dilaksanakan di Rumah Sakit Angkatan Laut dr Oepomo Surabaya yang mendapatkan terapi aminofilin intravena dan Rumah Sakit dr. Soewandi di Surabaya yang mendapatkan terapi salbutamol nebulizer.

\section{Variabel Penelitian}

Variabel bebas dalam penelitian ini adalah obat eksaserbasi asma yang diberikan untuk pasien asma. Variabel tergantung dalam penelitian ini adalah gangguan gastrointestinal. Ada dua kelompok obat eksaserbasi asma, dan setiap sampel penelitian akan mendapatkan salah satu dari kelompok obat eksaserbasi asma. Obat eksaserbasi asma diberikan saat sampel penelitian datang ke IGD dan bersedia menjadi sampel penelitian serta memenuhi kriteria inklusi dan eksklusi penelitian. Obat yang digunakan dalam penelitian pada kelompok A adalah aminofilin intravena selama $1 \mathrm{jam}$, pemberian perlahan lahan dengan loading dose 6 $\mathrm{mg} / \mathrm{kg} / \mathrm{jam}$ selama 20 menit, kemudian dilanjutkan dosis pemeliharaan dengan infus ( $\mathrm{NaCl}$ $0,9 \%$ ) sebesar $5 \mathrm{mcg} / \mathrm{kg} / \mathrm{jam}$ [19]; Sedangkan pada kelompok B adalah terapi salbutamol nebulizer selama 1 jam: $2,5 \mathrm{mg} / 2,5 \mathrm{ml}+2 \mathrm{~mL}$ saline [20].

Gangguan gastrointestinal dari aminofilin dan salbutamol yang diamati dalam penelitian ini adalah keluhan sampel penelitian terhadap gejala: mual dan muntah. Mual dan muntah diamati pada jam ke-0 (sebelum diberi terapi) dan jam ke-1 (1 jam sesudah diberi terapi). Pengamatan gangguan gastrointestinal dilakukan selama 1 jam [1]. Setiap kejadian mual muntah tersebut dinilai dengan Naranjo scale untuk mengetahui probabilitas kejadian mual muntahnya.

\section{Populasi dan Sampel}

Populasi adalah semua pasien yang mengalami eksaserbasi asma di rumah sakit di Surabaya. Sampel penelitian adalah pasien dengan eksaserbasi asma di rumah sakit di Surabaya yang memenuhi kriteria. Kriteria meliputi: berusia dewasa ( $\geq 18$ tahun) [21], bersedia menjadi subjek penelitian, tidak sedang hamil-menyusui atau menggunakan kontrasepsi oral [22], tidak memiliki gangguan fungsi renal atau gangguan hati [23], tidak memiliki gangguan pernafasan lain (TBC, pneumonia, emfisema), tidak mengonsumsi obat yang memengaruhi lambung seperti NSAID (Non Steroid Anti Inflamasi Drugs) dan PPI (Proton Pump Inhibitor), tidak merokok atau berhenti merokok $\geq 2$ tahun [24].

\section{Besar Sampel}

Berdasarkan rumus perhitungan sampel:

$$
n=\frac{\left(Z^{2} \times P \times Q\right)}{d^{2}}
$$

Bila:

$\mathrm{Z}_{0,05}=1,96$;

$P=0,0262$;

$Q=1-P=1-0,0262=0,9738$;

$d=0,05$

maka besar sampel penelitian $(\mathrm{n})$ minimal tiap kelompok dalam penelitian ini adalah 39 orang. 


\section{Metode Pengumpulan Data}

Sampel penelitian diberi terapi aminofilin intravena atau salbutamol nebulizer. Jam ke-0 (dilakukan sebelum diberi terapi) dilakukan pencatatan kondisi klinis oleh peneliti. Jam ke1 (1 jam setelah diterapi asma akut) pasien dipantau kejadian gangguan gastrointestinal (mual dan muntah) dari kondisi klinis.

\section{Analisis Data}

Analisis data yang digunakan dalam penelitian ini adalah uji Chi Square. Variabel yang diamati dalam penelitian ini adalah variabel kategori, yakni ada kategori mual muntah dan tidak mual muntah. Di dalam variabel kategori terdapat variabel ordinal yang menyatakan tingkatan kondisi pasien yang mengalami mual muntah yaitu kondisi sangat baik, kondisi baik, kondisi cukup baik dan kondisi buruk.

\section{HASIL}

\section{Distribusi Frekuensi Populasi dan Sampel Penelitian}

Jumlah populasi dalam penelitian ini sejumlah 37 pasien, yang diperoleh dari banyaknya pasien yang datang ke IGD dan diagnosis eksaserbasi asma oleh dokter yang bertugas di IGD tersebut. Dari 37 pasien yang mengalami serangan asma selama Bulan Oktober 2014 sampai Februari 2015, jumlah pasien yang bersedia terlibat dalam penelitian sebagai sampel penelitian sejumlah 20 pasien yang memenuhi kriteria inklusi dan kriteria eksklusi terbagi dalam 2 kelompok yaitu kelompok A (7 pasien) dan kelompok B (13 pasien) (Tabel 1).

Tabel 1

Distribusi Frekuensi Sampel Penelitian

\begin{tabular}{|c|c|c|c|c|c|c|}
\hline \multicolumn{3}{|c|}{ Karakteristik } & \multicolumn{2}{|c|}{ Kelompok A (n: 7) } & \multicolumn{2}{|c|}{ Kelompok B (n: 13) } \\
\hline & & & Frekuensi & $\begin{array}{c}\text { Persentase } \\
\text { (\%) }\end{array}$ & Frekuensi & $\begin{array}{c}\text { Persentase } \\
\text { (\%) }\end{array}$ \\
\hline Jenis & Perempuan & & 4 & 57,14 & 7 & 53,85 \\
\hline Kelamin & Laki-laki & & 3 & 42,85 & 6 & 46,15 \\
\hline Usia & $17-25$ & & 1 & 14,29 & 3 & 23,08 \\
\hline \multirow[t]{5}{*}{ (Tahun) } & $26-35$ & & 2 & 28,57 & 0 & 0 \\
\hline & $36-45$ & & 2 & 28,57 & 2 & 15,38 \\
\hline & $46-55$ & & 1 & 14,29 & 4 & 30,77 \\
\hline & $56-65$ & & 1 & 14,29 & 3 & 23,08 \\
\hline & $>65$ & & 0 & 0 & 1 & 7,69 \\
\hline \multirow[t]{4}{*}{ Pekerjaan } & Pelajar & & 1 & 14,29 & 2 & 15,38 \\
\hline & Karyawan swasta & & 2 & 28,57 & 3 & 23,08 \\
\hline & Wiraswasta & & 3 & 42,86 & 4 & 30,77 \\
\hline & Tidak bekerja & & 1 & 14,29 & 4 & 30,77 \\
\hline \multirow{4}{*}{$\begin{array}{l}\text { Penyakit } \\
\text { penyerta } \\
\text { (selain } \\
\text { asma) }\end{array}$} & Hipertensi & & 1 & 14,28 & 1 & 7,69 \\
\hline & $\begin{array}{l}\text { Hipertensi }+ \text { Kolesterol } \\
\text { Hiperurisemia }\end{array}$ & + & 0 & 0 & 1 & 7,69 \\
\hline & $\begin{array}{l}\text { Diabetes Mellitus tipe } 2 \\
\text { dyslipidemia }\end{array}$ & & 0 & 0 & 1 & 7,69 \\
\hline & Tanpa penyakit penyerta & & 6 & 85,71 & 10 & 76,92 \\
\hline
\end{tabular}

\section{Distribusi Frekuensi Hasil Kejadian Adverse Drug Reaction (ADR) Penelitian}

Kejadian gangguan gastrointestinal (mual dan muntah) pada penelitian ini diamati pada jam 0 (sebelum diberi terapi) dan jam ke 1 (sesudah diberi terapi). Kondisi pasien sangat baik dengan kuesioner adalah pasien tidak mual dan tidak muntah atau pasien mual tidak mengganggu aktivitas sama sekali dan tidak muntah. Kondisi pasien baik adalah pasien mual tetapi kadang-kadang mengganggu aktivitas serta tidak muntah [25]. Pada pasien kelompok $A$ yang mengalami ADRs sebanyak 1 orang, tidak mengalami ADRs sebanyak 6 orang. Sedangkan pada pasien kelompok B yang tidak mengalami ADRs sebanyak 13 orang. Data distribusi 
Amelia, L., et al., Membandingkan Kejadian Gangguan Gastrointestinal Penggunaan Aminofilin dan Salbutamol pada Pasien Eksaserbasi Asma di Surabaya, KELUWIH: Jurnal Kesehatan dan Kedokteran, Vol.1(1), 1-10, Desember 2019.

https://doi.org/10.24123/kes dok.v1i1.2487

frekuensi hasil kejadian adverse drug reaction (ADRs) penelitian kelompok A dan kelompok B dapat dilihat pada Tabel 2.

Tabel 2

Profil Kejadian Mual Muntah yang Dialami Sampel Penelitian

\begin{tabular}{|c|c|c|c|c|c|c|c|c|c|c|c|c|}
\hline \multirow[b]{3}{*}{ 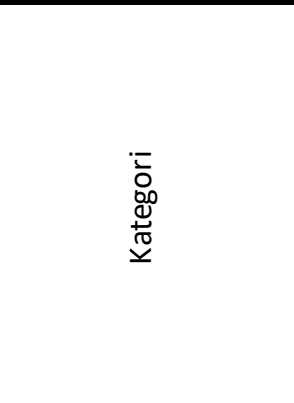 } & \multicolumn{6}{|c|}{ Kelompok A } & \multicolumn{6}{|c|}{ Kelompok B } \\
\hline & \multicolumn{2}{|c|}{ Jam ke-0 } & \multicolumn{2}{|c|}{ Jam ke-1 } & \multicolumn{2}{|c|}{$\begin{array}{l}\text { Jam ke-0 } \\
\text { dan ke-1 }\end{array}$} & \multicolumn{2}{|c|}{ Jam ke-0 } & \multicolumn{2}{|c|}{ Jam ke-1 } & \multicolumn{2}{|c|}{$\begin{array}{l}\text { Jam ke-0 } \\
\text { dan ke-1 }\end{array}$} \\
\hline & $\begin{array}{l}\bar{y} \\
\bar{d} \\
\frac{v}{v} \\
\frac{d}{L}\end{array}$ & 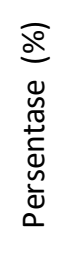 & $\begin{array}{l}\bar{y} \\
\bar{d} \\
\frac{d}{d} \\
\frac{v}{d}\end{array}$ & 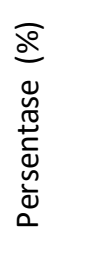 & $\begin{array}{l}\bar{n} \\
\frac{n}{d} \\
\frac{\vec{v}}{d} \\
\frac{d}{L}\end{array}$ & 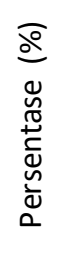 & $\begin{array}{l}\bar{y} \\
\frac{\bar{d}}{2} \\
\frac{v}{d} \\
\bar{L}\end{array}$ & 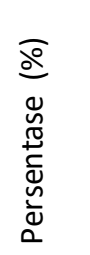 & $\begin{array}{l}\bar{y} \\
\frac{\bar{d}}{2} \\
\frac{v}{d} \\
\bar{L}\end{array}$ & 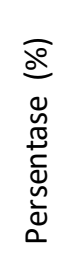 & $\begin{array}{l}\bar{w} \\
\frac{\bar{d}}{d} \\
\frac{v}{d} \\
\frac{d}{L}\end{array}$ & 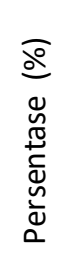 \\
\hline $\begin{array}{l}\text { Tidak ada mual- } \\
\text { muntah }\end{array}$ & 7 & 100 & 6 & 85,71 & 7 & 100 & 13 & 100 & 13 & $\begin{array}{l}10 \\
0\end{array}$ & 13 & 100 \\
\hline $\begin{array}{l}\text { Mual-muntah } \\
\text { (skor:0) }\end{array}$ & 0 & 0 & 1 & 14,29 & 0 & 0 & 0 & 0 & 0 & 0 & 0 & 0 \\
\hline $\begin{array}{l}\text { Mual-muntah } \\
\text { (skor:1) }\end{array}$ & 0 & 0 & 0 & 0 & 0 & 0 & 0 & 0 & 0 & 0 & 0 & 0 \\
\hline $\begin{array}{l}\text { Mual-muntah } \\
\text { (skor:2) }\end{array}$ & 0 & 0 & 0 & 0 & 0 & 0 & 0 & 0 & 0 & 0 & 0 & 0 \\
\hline $\begin{array}{l}\text { Mual-muntah } \\
\text { (skor:3) }\end{array}$ & 0 & 0 & 0 & 0 & 0 & 0 & 0 & 0 & 0 & 0 & 0 & 0 \\
\hline
\end{tabular}

Mual-muntah (skor:0) : Mual muntah i, yakni jumlah skor pertanyaan 1 dan 2 dari kuesioner mual muntah dengan hasil skor 0 , yakni kondisi pasien sangat baik

Mual-muntah (skor:1) : Mual muntah ii, yakni jumlah skor pertanyaan 1 dan 2 dari kuesioner mual muntah dengan hasil skor 1, yakni kondisi pasien baik

Mual-muntah (skor:2) : Mual muntah iii, yakni jumlah skor pertanyaan 1 dan 2 dari kuesioner mual muntah dengan hasil skor 2, yakni kondisi pasien cukup baik

Mual-muntah (skor:3) : Mual muntah iv, yakni jumlah skor pertanyaan 1 dan 2 dari kuesioner mual muntah dengan hasil skor 3, yakni kondisi pasien buruk

Kondisi pasien sangat baik dengan kuesioner adalah pasien tidak mual dan tidak muntah atau pasien mual tidak mengganggu aktivitas sama sekali dan tidak muntah. Kondisi pasien baik adalah pasien mual tetapi kadang-kadang mengganggu aktivitas serta tidak muntah [25].

\section{Penyajian Perhitungan Naranjo Scale pada Setiap Kejadian Mual Muntah yang dialami Sampel Penelitian Setelah diberi Terapi Aminofilin Intravena}

Mengetahui kejadian mual muntah pada penggunaan obat aminofilin berdasarkan probabilitasnya digunakan Naranjo Scale. Naranjo Scale digunakan untuk menguatkan bukti suatu gejala adalah ADR, sehingga untuk pasien yang diduga mengalami ADR seperti mual muntah dapat dihitung probabilitasnya dengan menggunakan Naranjo Scale.

Pasien yang mengalami mual pada saat jam ke-1. Pasien ini berasal dari kelompok $A$ kondisi saat MRS atau pada saat jam ke-0tidak mengalami mual. Setelah diterapi selama 1 jam pasien mengeluhkan agak mual sehingga pasien ini diduga mengalami ADR mual sehingga digunakan perhitungan Naranjo Scale untuk menguatkan bukti terjadinya ADR mual. Setelah 
Amelia, L., et al., Membandingkan Kejadian Gangguan Gastrointestinal Penggunaan Aminofilin dan Salbutamol pada Pasien Eksaserbasi Asma di Surabaya, KELUWIH: Jurnal Kesehatan dan Kedokteran, Vol.1(1), 1-10, Desember 2019.

dihitung dengan Naranjo scale total hasil akhirnya diperoleh total nilai sejumlah 3 (Tabel 3) sehingga penafsiran hasil Naranjo scale cukup mungkin ADR mual.

Tabel 3

Perhitungan Naranjo Scale untuk Mual Muntah

\begin{tabular}{|c|c|c|c|c|c|}
\hline \multirow{2}{*}{ No. } & \multirow{2}{*}{ Pertanyaan } & \multicolumn{3}{|c|}{ Pilihan Jawaban } & \multirow{2}{*}{$\begin{array}{l}\text { Jawaban: } \\
\text { (Nilai) }\end{array}$} \\
\hline & & Ya & Tidak & Tidak Tahu & \\
\hline 1 & $\begin{array}{l}\text { Apakah ada laporan efek samping obat yang } \\
\text { serupa? }\end{array}$ & +1 & 0 & 0 & +1 \\
\hline 2 & $\begin{array}{l}\text { Apakah efek samping obat terjadi setelah } \\
\text { pemberian obat yang dicurigai? }\end{array}$ & +2 & -1 & 0 & +2 \\
\hline 3 & $\begin{array}{l}\text { Apakah efek samping obat membaik setelah } \\
\text { obat dihentikan atau obat antagonis khusus } \\
\text { diberikan? }\end{array}$ & +1 & 0 & 0 & 0 \\
\hline 4 & $\begin{array}{l}\text { Apakah efek samping obat terjadi berulang } \\
\text { setelah obat diberikan kembali? }\end{array}$ & +2 & -1 & 0 & 0 \\
\hline 5 & $\begin{array}{l}\text { Apakah ada alternative penyebab yang dapat } \\
\text { menjelaskan yang kemungkinan } \\
\text { terjadinya efek samping obat? }\end{array}$ & -1 & +2 & 0 & 0 \\
\hline 6 & $\begin{array}{l}\text { Apakah efek samping obat muncul } \\
\text { kembali ketika plasebo diberikan? }\end{array}$ & -1 & +1 & 0 & 0 \\
\hline 7 & $\begin{array}{l}\text { Apakah obat yang dicurigai terdeteksi di } \\
\text { dalam darah atau cairan tubuh lainnya } \\
\text { dengan konsentrasi yang toksik? }\end{array}$ & +1 & 0 & 0 & 0 \\
\hline 8 & $\begin{array}{l}\text { Apakah efek samping obat bertambah } \\
\text { parah ketika dosis obat ditingkatkan atau } \\
\text { bertambah ringan ketika obat diturunkan } \\
\text { dosisnya? }\end{array}$ & +1 & 0 & 0 & 0 \\
\hline 9 & $\begin{array}{l}\text { Apakah pasien pernah mengalami efek } \\
\text { samping obat yang sama atau dengan obat } \\
\text { yang mirip sebelumnya? }\end{array}$ & +1 & 0 & 0 & 0 \\
\hline 10 & $\begin{array}{l}\text { Apakah efek samping obat dapat } \\
\text { dikonfirmasi dengan bukti yang obyektif? }\end{array}$ & +1 & 0 & 0 & 0 \\
\hline & \begin{tabular}{|c|} 
TOTAL \\
\end{tabular} & & & & 3 \\
\hline
\end{tabular}

\section{Uji Hipotesis}

Dalam penelitian ini uji statistik menggunakan uji chisquare. Uji chi square merupakan salah satu tes statistik non-parametrik yang perhitungannya didasarkan pada data hitung atau rangking. Kegunaan chi square adalah untuk mengestimasi kemungkinan adanya beberapa faktor kesalahan sampling. Oleh karena itu chisquare semata-mata menilai probabilitas untuk memperoleh perbedaan frekuensi yang nyata (hasil observasi) dengan frekuensi yang diharapkan atau frekuensi teoretik dalam kategori-kategori tertentu sebagai akibat kesalahan sampling. Bila diperoleh $p>0,05$ tidak signifikan, bila diperoleh $p<0,05$ signifikan (Hartono, 2008). Sebelum diberi terapi (pre-treatment) kondisi pasien sama yaitu tidak mual muntah. Setelah diberi terapi (post-treatment) dan diolah dengan menggunakan uji Chi Square dengan menggunakan SPSS diperoleh $P>0,05$ yaitu 0,162 yang berarti tidak signifikan, yakni tidak ada perbedaan kejadian gangguan gastrointestinal (mual muntah) pada terapi aminofilin dan salbutamol pada pasien eksaserbasi asma di Surabaya.

\section{BAHASAN}

Penelitian dilakukan dengan pengambilan data pada setiap rumah sakit dengan cara menunggu pasien datang ke IGD yang mengalami eksaserbasi asma. Pada penelitian ini dilakukan secara quasieksperimenta/karena penelitian ini tidak dilakukan secara acak. Pasien 
datang ke IGD yang mengalami eksaserbasi asma diambil secara purposive sampling, dan pasien tersebut memenuhi kriteria inklusi dan eksklusi yang mendukung tujuan penelitian. Kelemahan quasi eksperimental adalah kontrol terhadap variabel-variabel yang berpengaruh terhadap eksperimen tidak dilakukan, tidak adanya randomisasi, yang berarti pengelompokan anggota sampel pada kelompok eksperimen tidak dilakukan dengan random atau acak. Pada penelitian ini tidak dilakukan secara RCT (Randomized Controlled Trial) karena pada RCT terdapat kelompok kontrol, sedangkan pasien yang mengalami eksaserbasi asma tidak mungkin dijadikan kontrol karena harus segera mendapatkan terapi.

Cara pemberian intervensi berbeda pada setiap rumah sakit sehingga dapat memengaruhi hasil penelitian, manajemen IGD berbeda, selain itu intervensi dari setiap rumah sakit berbeda, sampel diberikan terapi sesuai dengan masing-masing rumah sakit. Quasi eksperimental dapat memengaruhi hasil penelitian ini karena validitas internalnya rendah sehingga faktor-faktor pengganggu dalam penelitian kurang terkontrol antara lain pengaruh perlakuan tenaga kesehatan terhadap sampel penelitian, perlakuan yang diberikan pada setiap rumah sakit berbeda karena manajemen setiap rumah sakit berbeda. Keterbatasan aktivitas fisik pasien secara umum dapat memengaruhi jawaban kuesioner mual muntah pertanyaan nomer 2, perasaan mual dapat mengganggu aktivitas sehari-hari pasien, seperti kemampuan untuk keluar dari tempat tidur, bisa bergerak bebas di tempat tidur, bisa berjalan normal, atau makan dan minum itu tetapi hal ini dapat memengaruhi jawaban dari pasien karena mengganggu aktivitas disebabkan oleh mual atau dari asma pasien.

Dalam penelitian ini yang diamati adalah keluhan sampel penelitian terhadap gejala mual dan muntah. Mual dan muntah diamati pada jam ke-0 (sebelum diberi terapi) dan jam ke-1 ( 1 jam sesudah diberi terapi). Identifikasi mual muntah juga memerlukan pertimbangan klinis dengan bantuan klinis atau tenaga kesehatan lain yaitu dokter untuk menilai gejala pasien atau keluhan pasien, melakukan diagnosis eksaserbasi asma pada pasien. Dalam menilai mual muntah pasien, terdapat kesulitan yaitu subjektivitas pasien sangat tinggi sehingga tergantung dari pengakuan pasien. Hal ini dikarenakan dalam menilai mual dan muntah tidak dapat dikonfirmasi dengan bukti yang objektif. Jika pada saat menilai mual muntah pasien tidak menunjukkan hasil, bukan berarti obat yang diberikan pada saat penelitian itu aman.

Penilaian ADRs dilakukan dengan pengamatan keluhan mual muntah sampel penelitian pada jam ke-0 dan jam ke-1. Penilaian ADRs dengan Naranjo scale dilakukan berdasarkan hasil wawancara dengan sampel penelitian dan diisi pada jam ke-1. Apabila sampel penelitian diduga mengalami mual/muntah akibat ADRs aminofilin/salbutamol. Dari 20 sampel penelitian 1 sampel mengalami ADRs mual dari terapi aminofilin. Untuk menunjang kemungkinan ADRs digunakan Naranjo scale untuk membuktikan bahwa keluhan mual muntah yang ada merupakan ADR atau bukan dari obat aminofilin. Setelah dijumlah total hasil Naranjo scale sebanyak 3 yang berarti cukup mungkin ADRs mual dari aminofilin.

Kesulitan yang dihadapi adalah adanya alternatif penyebab yang dapat menjelaskan kemungkinan terjadinya efek samping obat, seperti obat, makanan atau penyakit sehingga sulit menentukan ADRs berasal dari obat lain, makanan, penyakit atau obat aminofilin/sal butamol. Dalam mengisi nilai Naranjo terdapat pertanyaan yang sulit atau tidak mungkin dijawab antara lain ADRs muncul kembali ketika placebo diberikan, sedangkan dalam penelitian ini tidak diberikan placebo. ADRs bertambah parah ketika dosis ditingkatkan atau diturunkan, sedangkan jika pasien belum pernah mengalami peningkatan dosis atau penurunan dosis tidak ada data yang diperoleh. ADRs terjadi berulang setelah obat diberikan kembali, sedangkan dalam penelitian ini obat hanya diberikan satu kali sehingga tidak diketahui apakah obat diberikan kembali ADRs dapat terjadi berulang.

Untuk memastikan suatu gejala merupakan ADR atau bukan tidak cukup hanya peneliti sendiri, perlu supervisor lapangan (dokter/tenaga kesehatan lain). Keterbatasan penelitian selama penilaian ADR terkait gastrointestinal adalah jika sampel penelitian mengalami ADR mual muntah karena obat aminofilin/salbutamol pada saat jam ke-2 atau lebih karena penelitian hanya dilakukan pada jam ke-1 (sesudah diberikan terapi). Kesulitan dalam menilai 
mual muntah pasien yang diduga ADR adalah ADR tidak dapat dikonfirmasi dengan bukti yang objektif sehingga membutuhkan wawancara singkat dengan pasien atau keluarga pasien. Faktor-faktor lain yang bisa memengaruhi mual muntah pasien yang tidak dapat dikendalikan dalam penelitian adalah: (a) bau, karena bau yang tidak enak dapat merangsang rasa mual yang dapat memengaruhi hasil penelitian [26], (b) stres, karena stres yang dirasakan memiliki beban pekerjaan yang terlalu berat atau karena merasa kesal dan marah dapat memengaruhi kerja perut. Perut bisa tiba-tiba sakit saat benar-benar merasa kesal atau marah pada sesuatu. Sakit perut inilah yang kemudian bisa menyebabkan mual [27], (c) suhu ruangan IGD, karena jika suhu ruangan tinggi/pengap dapat menyebabkan bau seperti bau darah, bau urin sehingga dapat merangsang rasa mual [26].

Hasil analisis perbedaan kejadian gangguan gastrointestinal (mual muntah) pada penggunaan aminofilin dan salbutamol adalah sebelum diberi terapi (pretreatment) kondisi pasien sama yaitu tidak mual muntah. Setelah diberi terapi (post treatment) dan diolah dengan menggunakan uji Chi Square dengan menggunakan SPSS diperoleh $p>0,05$ yaitu 0,162 yang berarti tidak signifikan, artinya tidak ada perbedaan kejadian gangguan gastrointestinal (mual muntah) pada terapi aminofilin dan salbutamol pada pasien eksaserbasi asma di Surabaya.

Keterbatasan dalam uji chi square karena jumlah sampel yang kecil adalah hasil penelitian ini belum bisa digunakan sebagai pedoman dalam terapi asma. Untuk melengkapi diuji juga secara statistik. Ini menjadi sebuah masukan dalam penelitian meskipun hasil penelitian ini belum bisa dipakai sebagai pedoman dalam terapi asma. Faktor-faktor yang memengaruhi hasil penelitian adalah jumlah sampel yang diperoleh sedikit sehingga hasil penelitian ini belum dapat digunakan sebagai pedoman dalam terapi asma. Saran untuk penelitian lebih lanjut adalah waktu penelitian dilakukan lebih lama agar jumlah sampel yang didapatkan lebih banyak. Apabila salah satu obat menunjukkan risiko mual muntah lebih kecil, bukan berarti bahwa obat tersebut aman.

Kejadian ADRs terkait gastrointestinal dengan menggunakan Naranjo scale pada penggunaan aminofilin dari 7 sampel penelitian mengalami ADRs mual sebanyak 1 sampel sebesar $14,29 \%$, pada penelitian-penelitian sebelumnya diperoleh 5 pasien dari 20 pasien yang mengeluh atau menunjukkan gejala ADRs berupa mual sebesar $25 \%$ setelah mengonsumsi aminofilin [28], sehingga dapat dikatakan hasil penelitian ini sebanding dengan penelitian sebelumnya bahwa aminofil in dapat menyebabkan ADRs mual, aminofil in dapat menyebabkan mual muntah disebabkan oleh penghambatan PDE tertentu misalnya, PDE4 di pusat muntah [20], sedangkan kejadian ADRs terkait gastrointestinal pada penggunaan salbutamol dari 13 sampel penelitian tidak ada yang mengalami ADRs yaitu sebesar $0 \%$. Pada penelitian-penelitian sebelumnya terdapat 2 pasien dari 20 pasien yang mengeluh atau menunjukkan ADRs berupa mual sebesar $10 \%$ setelah mengonsumsi salbutamol [28], sehingga dapat dikatakan bahwa hasil penelitian initidak sebanding dengan penelitian-penelitian sebelumnya. Selama penilaian Naranjo scale terdapat kesulitan yang dihadapi oleh peneliti yaitu adanya alternatif penyebab yang dapat menjelaskan kemungkinan terjadinya efek samping obat, seperti obat, makanan atau penyakit sehingga sulit menentukan ADR berasal dari obat lain, makanan, penyakit atau obat aminofilin/salbutamol. Data yang diperoleh dari Naranjo scale berdasarkan ingatan pasien sehingga ada beberapa data tidak dapat diperoleh. Dalam penelitian ini tidak diberikan plasebo sehingga peneliti mengalami kesulitan untuk menilai naranjo scale pasien yang mengalami ADR.

\section{SIMPULAN}

Tidak ada perbedaan kejadian gangguan gastrointestinal (mual muntah) pada terapi aminofilin dan salbutamol pada pasien eksaserbasi asma di Surabaya. Namun kesimpulan penelitian ini belum dapat dipakai sebagai pedoman dalam terapi asma karena berbagai keterbatasan penelitian khususnya jumlah sampel yang diperoleh terlalu kecil dan penelitian selanjutnya disarankan agar dilakukan dalam waktu yang lebih lama dan jumlah sampel penelitian yang lebih banyak. Selain itu, pada 7 pasien dari penggunaan aminofilin ditemukan 
kejadian gangguan gastrointestinal pada kelompok aminofil in sebesar $14,29 \%$ sedangkan pada 13 pasien dari penggunaan salbutamol tidak ditemukan kejadian gangguan gastrointestinal pada kelompok Salbutamol.

\section{PUSTAKA ACUAN}

1. Global Initiative for Asthma (GINA), 2017, Global Strategy for Asthma Management \& Prevention (Update).

2. Leader WG, 2009, Pharmacotherapy Principles and Practice, 8th edition, Mc GrawHill Medical, New York, 209.

3. Oemiati R, Sihombing M, Qomariah, 2010, Faktor-Faktor yang Berhubungan dengan Penyakit Asma di Indonesia, Media Litbang Kesehatan, 20(1):41-49.

4. Kelly HW, Sorkness CA, 2008, Pharmacotherapy- A Pathophysiologic Approach, seventh edition, The Mc Graw - Hill Companies, United States, 463.

5. Barnes PJ, 2003, Theophylline, New Perspectives for Ald Drug. America Journal of Respiratory and Critical Care Meicine, 167: 813-818.

6. Lorensia A, Wahjuningsih E, Canggih B, Lisiska N. 2011. Pharmacist's Strategies in Treating Asthma Bronchiale Outpatient. Jurnal of Tropical Pharmacy and Chemistry, UNMUL, 1(3):177-191 (ISSN 2087-7099).

7. Lorensia A, Canggih B, Wijaya RI, 2013. Analisis Adverse Drug Reactions pada Pasien Asma di Suatu Rumah Sakit, Surabaya. Jurnal Farmasi Indonesia. 6(3):142-150 (ISSN 1412-1107).

8. Lorensia A, Wahjuningsih E, Supriadi, 2012, Keamanan Penggunaan Aminofilin pada Pengobatan Asma di Rumah Sakit , Jurnal Farmasi Klinik Indonesia, 1(4): 154-161.

9. Namazi, Vessal G, Hosshmand S; et al, 2010, A Drug Utilization Research on Aminophylline/Theophylline in Ali-Asghar Hospital, Shiraz, Southern Iran, Iranian Red Crescent Medical Journal, 12(2): 181-186.

10. Kementrian Kesehatan. 2015, Keputusan Menteri Kesehatan Republik Indonesia, Nomor 312/MENKES/SK/IX/2015, tentang Daftar Obat Essensial 2015, Jakarta, Kementerian Kesehatan Republik Indonesia.

11. Lorensia A, Ikawati Z, Andayani TM, Maranatha D, Wahyudi M. 2018. CYP1A2 Gene Polymorphism and Theophylline Level in Asthma. The Indonesian Biomedical Journal. 11(1):63-69. DOI: 10.18585/inabj.v11i1.475

12. Lorensia A, Ikawati Z, Andayani TM, Suryadinata RV, Hartoro KAA, Firanita LD. 2018. Efektifitas dan Risiko Toksisitas Aminofilin Intravena pada Pengobatan Awal. Indonesia journal of Clinical Pharmacy (IJCP), Padjajaran University. 7(2):78-88. https://doi.org/10.15416/ijcp.2018.7.2

13. Caffarelli C, Deriu FM, Terzi V; et al, 2000, Gastrointestinal Symptoms in Patients Asthma. Arch Dis Child, 82: 131-135.

14. Sweetman S, 2009, Martindale, The complete drug reference. 36th edition. Pharmaceutical Press, USA, 1132-1140.

15. Ohta K, Fukuchi Y, Grouse L; et al, 2004, A Prospective Clinical Study of Theophylline Safety in 3810 Elderly with Asthma or COPD, Respiratory Medicine 98, 1016-1024.

16. Informed Health Online, 2012, Fact Sheet: Heartburn and GERD, September 2012, (online), (http://www.ncbi.nlm.nih.gov/pubmedhealth/PMH0048152/.com diakses 25-07-2013)

17. Daniel E, Bercker, DDS, 2010, Nausea Vomiting and Hiccups : A Review of Mechanism and Treatment, Anesth Prog, 57: 150-157.

18. Complementary and Alternative Medicine, 2011, Asthma, Juni 2011, (online), (http://umm.edu/health/medical/altmed/condition/asthma.com diakses 4-08-2013).

19. Asthma Management Handbook, National Asthma Council Australia, 2006.

20. Barnard A, 2005, Management of an Acute Asthma Attack, Australian Family Physician, 34(7): 531-534. 
21. National Center for Chronic Disease Prevention and Health Promotion, 2011, Data Source with Asthma Content: Behavioral Risk Factor Surveillance System (BRFSS), (online), (http://www.cdc.gov/asthma/survey/brfss.pdf.com diakses 21-03-2014)

22. Ou Yang, Yang S, Neng CZ, et al, 2000, Role of Cytochrome P450 in Estradiol Metabolism in Vitro, Acta Pharmacol Sin, 22(2): 148-154.

23. Obase Y, Shimoda T, Kawano T; et al, 2003, Polymorphisms in The CYP1A2 Gene and Theophylline Metabolism in Patients With Asthma, Clinical Pharmacology and Therapeutics, 78(5): 468-474.

24. Anderson PO, Knoben JE, Troutman WG, 2002, Handbook Of Clinical Drug, $10^{\text {th }}$ edition, New York, Mc Graw Hill, 782-78.

25. Myles PS, Wengritzky R, 2012, Simplified Postoperative Nausea and Vomiting Impact Scale for Audit and Post-Discharge Review, British Journal of Anaesthesia, page 1-7.

26. Sotandyo N, 2007, Nutrisi pada Pasien Kankeryang Mendapatkan Kemoterapi, Indonesian Journal of Cancer, 4: 144-148.

27. Subekti T, 2011, Metode Relaksasi untuk Menurunkan Stres dan Keluhan Tukak Lambung pada Penderita Tukak Lambung Kronis, Jurnal Psikologi, 38(2): 147-163.

28. Denis Marta Ayunita, 2012, Studi Efek Samping Penggunaan Obat Aminofilin dan atau Salbutamol pada Pasien Rawat Inap dengan Kasus Asma di RS Paru Jember, Skripsi tidak dipublikasikan, Jember, Fakultas Farmasi Universitas Jember. 